\title{
ベクトル制御誘導電動機の電圧飽和を考慮した 弱め界磁制御による出力トルク特性の改善
}

\author{
正 員 上町 俊幸* 学生員 遠藤 亮* \\ 正 員 大石 潔**
}

Improvement of Output Torque Characteristic of Vector Controlled Induction Motor using Field-Weakening Control Considering Voltage Saturation

Toshiyuki Kanmachi*, Member, Ryo Endo*, Student Member, Kiyoshi Ohishi**, Member

This paper proposes a new field-weakening control considering voltage saturation for vector controlled induction motor. The proposed method improves the output torque characteristics in the field-weakening region. The effectiveness of proposed method is verified by the experimental results.

キーワード：ベクトル制御，電圧飽和，弱め界磁制御

Keywords: Vector control, Voltage saturation, Field-weakening control

\section{1. まえがき}

誘導電動機のベクトル制御において，電圧飽和を考慮し た制御法が開発されており ${ }^{(1)}$ ，これを瞬時空間べクトルイ ンバータ駆動のベクトル制御に適用する手法を提案してき た ${ }^{(2)}$ 。本稿では, 電圧飽和量を用いた弱め界磁制御法 ${ }^{(3)}$ と 瞬時空間ベクトルインバータの組み合わせにより，弱め界 磁領域において出力トルク特性を改善する手法を提案し, その有効性について述べる。

\section{2. 電圧飽和を考慮した弱め界磁制御法}

定格速度以上の高速領域では, 逆起電力の影響が大きく なるため，一般に弱め界磁制御が用いられる。従来の弱め 界磁制御では，(1) 式のように速度 $\omega_{m}$ に反比例した磁束指 令 $\phi_{2 d}^{*}$ を与えている。

$$
\phi_{2 d}^{*}=\phi_{2 d n}^{*} \frac{\omega_{m n}}{\omega_{m}}
$$

ただし， $\phi_{2 d n}^{*}$ : 定格磁束指令， $\omega_{m n}$ : 定格速度である。

高速領域では，励磁成分である $d$ 軸に比べ，磁束を回転 させる $q$ 軸電圧成分が大きくなるため，回転座標の $q$ 軸に おいて電圧飽和が生じると考えられる。しかし，従来法で は電圧飽和を考慮していないため，電圧飽和時に適切な磁 束指令が与えられているとはいえない。

\footnotetext{
*仙台電波工業高等専門学校

干 989-3128 仙台市青葉区愛子中央四丁目 16-1

Dept. of Elec. Cont. Eng., Sendai National College of Tech.

4-16-1, Ayashi-chuo, Aoba-ku, Sendai 989-3128

** 長岡技術科学大学

† 940-2188 新潟県長岡市上富岡町 1603-1

Dept. of Electric Eng., Nagaoka University of Technology

1603-1, Kamitomioka, Nagaoka, Niigata 940-2188
}

(2) 式は, 定常状態における誘導電動機の $q$ 軸の電圧方程 式である。高速領域で同期速度 $\omega$ が十分大きいとすれば， 逆起電力の項のみで近似できる。

$$
\begin{aligned}
v_{1 q} & =R_{1} i_{1 q}+\omega\left(\sigma L_{1} i_{1 d}+\frac{M}{L_{2}} \phi_{2 d}\right) \\
& \simeq \frac{\omega M}{L_{2}} \phi_{2 d} \ldots \ldots \ldots \ldots \ldots \ldots \ldots
\end{aligned}
$$

ただし， $R_{1}$ : 一次抵抗， $L_{1}, L_{2}$ :一次，二次インダクタンス， $M:$ 相互インダクタンス,$\sigma=1-M^{2} / L_{1} L_{2}$ である。

(2) 式において，電圧飽和により $v_{1 q}$ が制限された時，右 辺の $\omega$ に影響が及ばないよう, 磁束 $\phi_{2 d}$ を小さくする必要 がある。光こで，(2) 式の関係を用いて (3) 式のように磁束 指令を修正することで, インバータ電圧飽和量に応じた磁 束指令值を与える ${ }^{(3)}$ 。

$$
\phi_{2 d}^{*}=\phi_{2 d n}^{*} \frac{\omega_{m n}}{\omega_{m}}-\frac{L_{2}}{\omega M} \Delta v_{1 q}
$$

3. 弱め界磁を用いたベクトル制御システム

図 1 は，提案する弱め界磁制御法を用いた誘導電動機の ベクトル制御システムである。磁束制御系において , 指令 值 $\phi_{2 d}^{*}$ と磁束推定値 $\hat{\phi}_{2 d}$ が一致するよう PI 制御を行い, $d$ 軸電流指令 $i_{1 d}^{*}$ を決定する。また, 速度制御系からは, $q$ 軸 電流指令 $i_{1 q}^{*}$ が与えられる。光れ午れの指令値と実電流 $i_{1 d}$, $i_{1 q}$ が一致するよう電流の PI 制御を行い, 瞬時空間ベクト ルインバータの電圧指令 $v_{1 d}^{*}, v_{1 q}^{*}$ が決定される。瞬時空間 ベクトルインバータでは, 零電圧ベクトル以外に 2 つの空 間電圧ベクトルが出力されるが，これら 2 つの電圧べクト ルの出力期間 $t_{1}, t_{2}$ を適切に与えることで, 電圧指令通り 


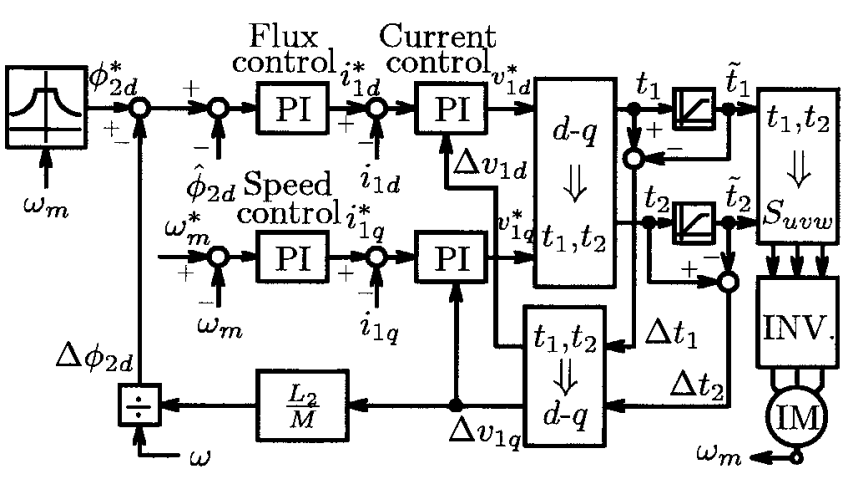

図 1 弱め界磁を用いたベクトル制御システム

Fig. 1. Vector control system with field-weakening control.

の電圧を出力し, 誘導電動機を駆動する。

ここで電圧指令がインバータの出力限界を越える場合は, $t_{1}+t_{2}$ がサンプリング周期 $T_{s}$ を上回るため，(4) 式のよう に電圧出力期間を均等に短縮する。

$$
\tilde{t}_{1}=\frac{T_{s}}{t_{1}+t_{2}} t_{1}, \quad \tilde{t}_{2}=\frac{T_{s}}{t_{1}+t_{2}} t_{2} .
$$

このとき, 電圧飽和量が (5) 式, (6) 式より求められる。

$$
\begin{aligned}
& {\left[\begin{array}{l}
\Delta v_{1 \alpha} \\
\Delta v_{1 \beta}
\end{array}\right]=\sqrt{\frac{2}{3}} \frac{V_{D C}}{T_{s}}\left[\begin{array}{cc}
v_{1 \alpha} & v_{2 \alpha} \\
v_{1 \beta} & v_{2 \beta}
\end{array}\right]\left[\begin{array}{c}
\Delta t_{1} \\
\Delta t_{2}
\end{array}\right]} \\
& {\left[\begin{array}{c}
\Delta v_{1 d} \\
\Delta v_{1 q}
\end{array}\right]=\left[\begin{array}{cc}
\cos \theta & \sin \theta \\
-\sin \theta & \cos \theta
\end{array}\right]\left[\begin{array}{l}
\Delta v_{1 \alpha} \\
\Delta v_{1 \beta}
\end{array}\right] \ldots}
\end{aligned}
$$

ただし， $\Delta t_{1}=t_{1}-\tilde{t}_{1}, \Delta t_{2}=t_{2}-\tilde{t}_{2}, v_{1 \alpha}, v_{1 \beta}, v_{2 \alpha}, v_{2 \beta}$ : 出力電圧べクトルの $\alpha-\beta$ 静止座標軸成分である。

この $\Delta v_{1 q}$ を用いて，弱め界磁領域での磁束指令值を (3) 式のように修正している。また , $\Delta v_{1 d}, \Delta v_{1 q}$ をフィードバッ クして電流制御系のPI 入力を修正し，積分演算を再計算す ることで電圧飽和対策も行っている(2)。

\section{4. 実験結果}

$1.5 \mathrm{~kW}, 60 \mathrm{~Hz}, 4$ 極の誘導電動機を用いて，定常状態の 出カトルク特性を測定した。图 2 は, 指令速度から $0.1 \% の$ 誤差範囲内で速度制御が達成できるときの, 最大出カトル クを示している。定格速度以下の領域では，リミッタによ り出カトルクが制限されるため両手法に差はないが, 弱め界 磁領域では提案法の出力トルクが, 従来法より平均 $11 \%$ 上 昇している。また, 図中の A, B 点において両手法の相電 流を比較すると，提案法の振幅が1〜4\%小さくなっている。 图 3 は, 速度指令を $350 \mathrm{rpm}$ から $3000 \mathrm{rpm}$ に変化させた ときの速度 $\omega_{m}$ と磁束指令值 $\phi_{2 d}^{*}$ の波形を示している。こ のとき， $3000 \mathrm{rpm}$ において 58\%の負荷が印加されるよう， 負荷発電機に抵抗を接続している。定格速度以上で弱め界 磁制御が行われているが, 提案法では磁束指令值が修正さ れるため, 従来法より小さな磁束指令となっている。しか し, 磁束の修正により出カトルクか増大し, 結果的に, よ り高速な過渡応答が得られている。

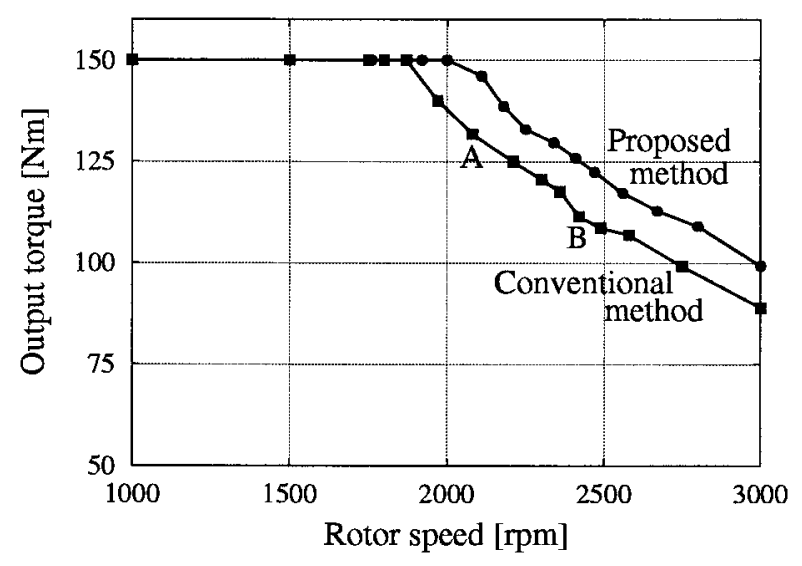

図 2 トルク出力特性

Fig. 2. Output torque characteristics.

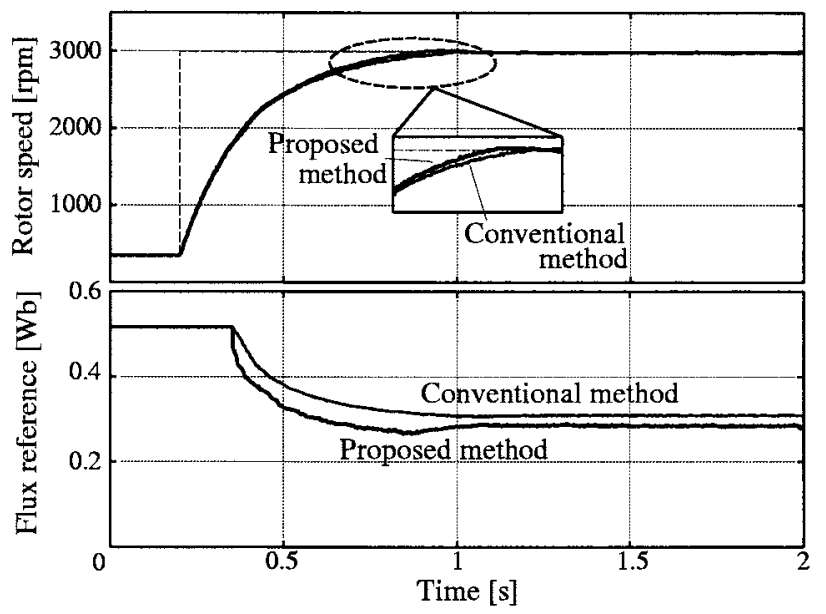

図 3 過渡応答特性

Fig. 3. Transient responce.

5. むすび

本稿では, 瞬時空間ベクトルインバータ駆動のベクトル 制御と，電圧飽和を考慮した弱め界磁制御を組み合わせた システムを提案した。キャリア変調インバータより出力電 圧範囲が広くなったことや，電圧飽和が生じても適切な弱 め界磁指令が与えられたことにより，弱め界磁領域におけ る出カトルク特性か改善された。

(平成 16 年 10 月 14 日受付, 平成 17 年 1 月 11 日再受付)

$$
\text { 文献 }
$$

(1) K. Ohishi, E. Hayasaka, T. Nagano, and M. Harakawa: "Speed Servo System Considering Voltage Saturation of Indirect Vector Control System", $T$. IEE Japan, Vol.122-D, No.2, pp.120-127 (2002-2) (in Japanese) 大石 潔・早坂恵美子・長野鉄明・原川雅哉 : 「間接形ベクトル制御 における電圧飽和を考慮した速度サーボ系の一構成」, 電学論 $\mathrm{D}, \mathbf{1 2 2}$, 2, pp.120-127 (2002-2)

( 2 ) T. Kanmachi, R. Endo, and K. Ohishi: "High Performance Space Voltage Vector Controlled Inverter Considering Voltage Saturation for Speed Servo System of Induction Motor", $10^{\text {th }}$ EPE, No.245, Toulouse, France (2003-9)

(3) Y. Sato and K. Ohishi: "An Approach of Drive Method of Indiredt Vector Control Considering Voltage Saturation at Constant Output Power RegionSecond Report-", National Convention Record IEE Japan, No.4-140, pp.227-228 (2002) (in Japanese)

佐藤康幸・大石 潔: 「電圧飽和を考慮した間接形べクトル制御誘 導機の定出力領域における駆動法一第二報一」, 平 14 電気学会全大, No.4-140, pp.227-228 (2002) 